\title{
The Potency of Trichoderma sp. as A Biocontrol Agent against Fusarium sp. Pathogen of Porang (Amorphophallus muelleri Blume) Tuber
}

\author{
Nindi Nazula Fajarini, Rodiyati Azrianingsih *, Suharjono \\ Department of Biology, Faculty of Mathematics and Natural Sciences, Brawijaya University, Malang 65145, \\ Indonesia
}

Article history:

Submission April 2019

Revised August 2019

Accepted November 2019

*Corresponding author:

E-mail: rodiyati@ub.ac.id

\begin{abstract}
Porang (Amorphophallus muelleri Blume) has high economic value in Asia. Porang tuber is high in glucomannan and thus becomes one of the exportable food commodities. Porang plants are susceptible to wilt disease caused by Fusarium sp. Trichoderma sp. has the ability to inhibit the growth of pathogenic fungi such as Fusarium sp. This research aimed to study the potency of Trichoderma sp. in controlling the growth of Fusarium sp. Trichoderma sp. was isolated from the rhizosphere soil in A. muelleri plantation, while Fusarium sp. was isolated from A. muelleri tuber infected by Fusarium. The fungi isolates were identified phylogenetically based on the similarity of Internal Transcribed Spacers (ITS) sequence. Both fungi were antagonistically assessed based on the dual culture method. The antagonistic assay showed that the two isolates of Trichoderma had the potency to inhibit the growth of the two isolates of Fusarium. Trichoderma sp. 2 has higher antagonistic potency than Trichoderma sp. 1. Based on ITS sequence similarity, Trichoderma sp. 1 and Trichoderma sp. 2 were identified as Trichoderma longipale and Trichoderma spirale respectively, while both pathogenic Fusarium were identified as Fusarium oxysporum. Trichoderma spirale therefore could be developed as a biopesticide agent in controlling Fusarium oxysporum.
\end{abstract}

Keywords: Amorphophallus oncophyllus, Antagonistic Fungi, Fungicide, ITS Sequence, Yellow Konjac

\section{Introduction}

Porang (Amorphophallus muelleri Blume) belongs to the Araceae Family and grows well as an agroforestry crop in Java [1]. This plant's tuber is known having high economic value in Asia [2] due to its up to $80 \%$ glucomannan content [3]. Therefore, it becomes one of the widely-exported commodities for food needs. The market demand for Porang is higher than its production. This is due to the improper postharvest handling that is potential to trigger the infection by the pathogenic microorganisms such as fungi. Several types of fungus that can infect tubers are Phytophthora infestans [3], Fusarium oxysporum [4], and Botrytis cinerea [5].

Fusarium species are the plant pathogens that are well-known as the cause of economic damage in agricultural productions [6]. They are economically harmful because most of the members are the causal agents of root rot in the agricultural crops around the world [7]. Fusarium wilt spread in many Asian countries such as India, Indonesia, Malaysia, Taiwan, and Philippines [8]. Fusarium species have been found to infect agricultural crops such as banana [9], strawberry [10], chili [11] and konjac [5].

Chemical compounds have been used to control plant diseases, but the overuse of the compounds has caused the development of pathogens resistant to fungicides [12]. The biocontrol agents have the ability to compete with pathogens for nutrients and to inhibit the pathogen's growth by secreting antibiotics or reducing the pathogen populations through parasitism [13] and activation of

\section{How to cite:}

Fajarini NN, Azrianingsih R, Suharjono (2020) The Potency of Trichoderma sp. as A Biocontrol Agent Against Fusarium sp. Pathogen of Porang (Amorphophallus muelleri Blume) Tuber. Journal of Tropical Life Science 10 (1): 37 - 42. doi: 
multiple mechanisms [14].

The rhizosphere is a part of the soil around the roots of plants and has a role as an external defense for plants against the attack of root pathogens. A population of microorganisms in the rhizosphere is usually more numerous and diverse than in the non-rhizosphere soil [15]. They can be beneficial to the plant since they suppress or harm the pathogens through the competition for nutrients [16].

The soil microbes such as Trichoderma, Penicillium, etc., can be some better alternatives since they reside in the rhizosphere of the crop plants and are effective to suppress the pathogens [17]. Trichoderma is easily isolated from soil, decaying wood, and other forms of plant organic matter. It is proven to have induced the programmed cell death in plant fungal pathogen such as Fusarium sp. [18].

Chemical fungicide is one of the methods to eradicate the plant diseases, but it is rarely found in the management of postharvest pathogens of $A$. muelleri. The previous study has identified the postharvest pathogens in A. muelleri without conducting any antagonistic assay [5]. Based on the potency of Trichoderma in suppressing the development of pathogenic fungi such as Fusarium, it is necessary to conduct a research to determine the antagonistic inhibition level on the growth of pathogenic fungi (Fusarium) found in Porang tubers.

\section{Material and Methods \\ Isolation of fungal cultures}

Two isolates of Fusarium sp. (F1 and F2) were isolated from the tubers of A. muelleri aged 6 weeks and 10 weeks after the harvest in Bantur Village, Malang Regency, East Java Province, Indonesia. The tuber's infected vascular tissue was cut with a sterile knife $\left(\mathrm{ca} .1 \times 1 \times 0.2 \mathrm{~cm}^{3}\right)$. The samples were sterilized in $5.25 \%(\mathrm{w} / \mathrm{v})$ of sodium hypochlorite solution for 30 seconds and were rinsed thrice with sterile water for 1 minute and then were placed on the surface of Potato Dextrose Agar (PDA) medium. The PDA medium contained $50 \mathrm{ppm}$ streptomycin to minimize the chance of bacterial growth. Plates were incubated at $28 \pm 2{ }^{\circ} \mathrm{C}$ and were observed periodically. The fungi were identified following the sporulation and a single colony was picked for purifying the culture and then was preserved at $0-4{ }^{\circ} \mathrm{C}$ on PDA slants [7].
Trichoderma isolates were obtained from the rhizospheric soil of A. muelleri crops in Bantur, Malang, East Java, Indonesia. The soil samples were collected from various sources at three locations of $A$. muelleri fields. The samples were put into a cool box container to maintain the viability of the fungi. For fungal isolation, $25 \mathrm{~g}$ of rhizospheric soil sample was suspended in $225 \mathrm{~mL}$ of $0.85 \%(\mathrm{w} / \mathrm{v})$ sodium chloride solution and manually homogenized for a few minutes. $1 \mathrm{~mL}$ of suspension was diluted into $9 \mathrm{~mL}$ of $0.85 \%(\mathrm{w} / \mathrm{v})$ sodium chloride solution in the test tube and then shaken until being homogeneous [19]. Afterwards, a serial dilution performed up to $10^{-5}$ dilutions [20]. $0.1 \mathrm{~mL}$ suspension of soil samples on each dilution was inoculated into the Petri dishes using the "poured plate" method with PDA medium containing $50 \mathrm{ppm}$ of streptomycin to prevent bacterial growth. Cultures were incubated at $28 \pm 2{ }^{\circ} \mathrm{C}$ for $5-7$ days and the number of growing colonies were calculated [21].

\section{Fungal morphological characterization}

Each isolate of fungi was purified from a single spore. A single spore of fungal isolates was grown for 10-15 days on PDA medium containing $50 \mathrm{ppm}$ of streptomycin. The macroscopic colony culture was characterized by having the color, shape, and texture of the colony. The microscopic features of hyphae and reproductive structure were characterized based on Ellis et al. [22].

\section{Antagonist assay of Trichoderma isolates against Fusarium sp.}

The antagonist assay corresponds to the dual culture method by Sibounnavong [23]. A single spore of Trichoderma isolate was grown together with Fusarium isolate spore in a PDA at a distance of $3 \mathrm{~cm}$ (Figure 1). The culture was incubated at $28 \pm 2{ }^{\circ} \mathrm{C}$ for 7 days. As a control, Fusarium isolates spore is grown on the media without Trichoderma isolate. Each experiment was conducted with three replications. The control and the antagonist assay were observed on the $4^{\text {th }}$ day to the $7^{\text {th }}$ day of incubation. The ability of Trichoderma to inhibit the Fusarium growth can be calculated by the Percentage Inhibition of Radial Growth (PIRG) formula.

$$
\operatorname{PIRG}(\%)=\frac{R 1-R 2}{R 1} \times 100 \%
$$


Note:

$\mathrm{R} 1$ : diameter of pathogens colonies on control media (cm)

R2: diameter of pathogens colonies on dual culture media $(\mathrm{cm})$
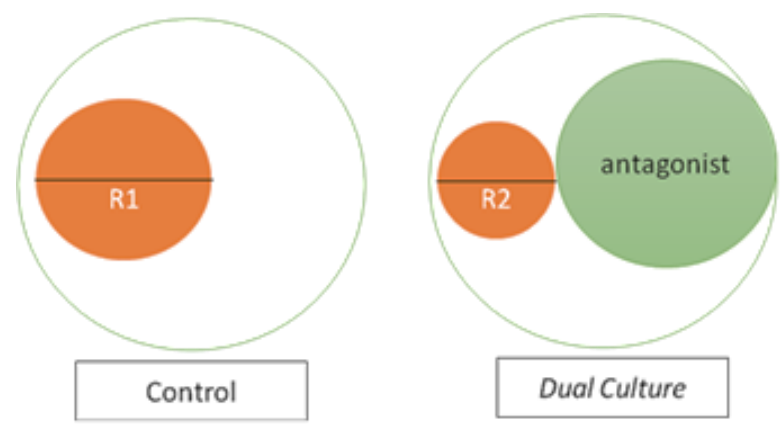

Figure 1. Dual culture antagonism assay

\section{Fungal identification base on ITS sequence}

Phylogenetic identification of Fusarium and Trichoderma isolates was carried out based on the conserved ribosomal ITS region. Genomic DNA was extracted using the i-genomic Soil DNA Extraction Mini Kit Protocol (USA). The sequence of ITS regions was amplified using the universal primer ITS5 (5'-GGAAGTAAAAGTCGTAACAAGG3') and ITS4 (5'-TCCTCCGCTTATTGATATGC-3') [24].

The amplification of ITS region was performed on a Thermal Cycler with GoTaq ${ }^{\circledR}$ Green Master Mix, $2 \times 25 \mu \mathrm{L} ; 10 \mu \mathrm{M}$ upstream primer $0.5-5.0 \mu \mathrm{L} ; 10 \mu \mathrm{M}$ downstream primer $0.5-5.0$ $\mu \mathrm{L} ;<250$ ng DNA template $1-5 \mu \mathrm{L}$; NucleaseFree Water to $50 \mu \mathrm{L}$ N.A [25] with modifications. The DNA sequence amplification program of PCR machine consists of an initial denaturation at $95^{\circ} \mathrm{C}$ for 2 minutes followed by 35 cycles: denaturation at $94^{\circ} \mathrm{C}$ for 30 seconds, annealing $55^{\circ} \mathrm{C}$ for 1 minute, and extension $72^{\circ} \mathrm{C}$ for 1 minute, and a final extension at $72^{\circ} \mathrm{C}$ for 5 minutes. The amplified PCR products were verified on an electrophoresis gel agarose $(1.5 \% \mathrm{w} / \mathrm{v})$ in $1 \mathrm{X}$ TAE buffer at $65 \mathrm{~V}$ for 150 minutes. The ITS sequence was purified and sequenced at First Base, Malaysia. The ITS nucleotide sequences for each isolate were compared to those in the public domain databases of the National Center for Biotechnology Information (NCBI); www.ncbi.nih.gov using the Basic Local Alignment Search Tool for Nucleotide Sequences (BLASTN). The alignment of ITS DNA sequences was done using the ClustalW pro-

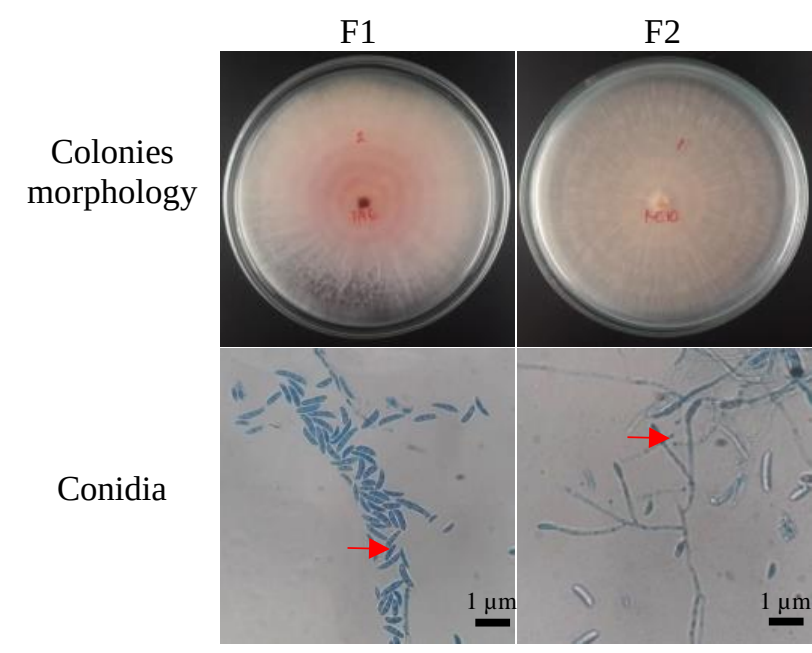

Figure 2. Morphological characteristic of Fusarium sp.
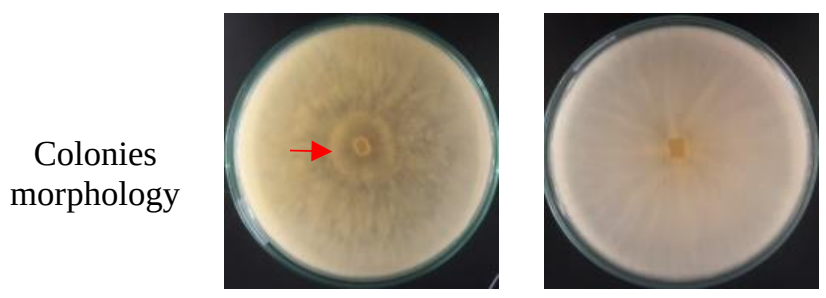

Conidia and

Conidiophores
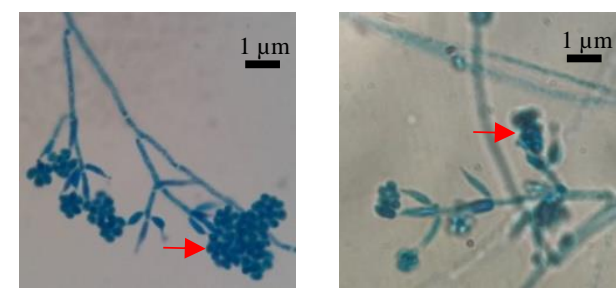

Figure 3. Morphological characteristic of Trichoderma sp.

gram. The phylogenetic tree was constructed using the MEGA version 6 program with 1000 bootstrap, while the inversion was conducted using the Maximum Likelihood or Unweighted Pair Group Method for Arithmetic Analysis (UPGMA) [24].

\section{Results and Discussion Morphological characteristic of Fusarium iso-} late

The two Fusarium isolates were isolated. According to Ellis [22], Fusarium grows rapidly with pale-white or bright-colored colonies with or without air mycelium (Figure 2). Asexual reproduction in Fusarium oxysporum is accomplished by macroconidia, microconidia and chlamydospores [26]. Microconidia was found in the monofialid and oval or fusiform [27]. Macroconidia are produced 
A
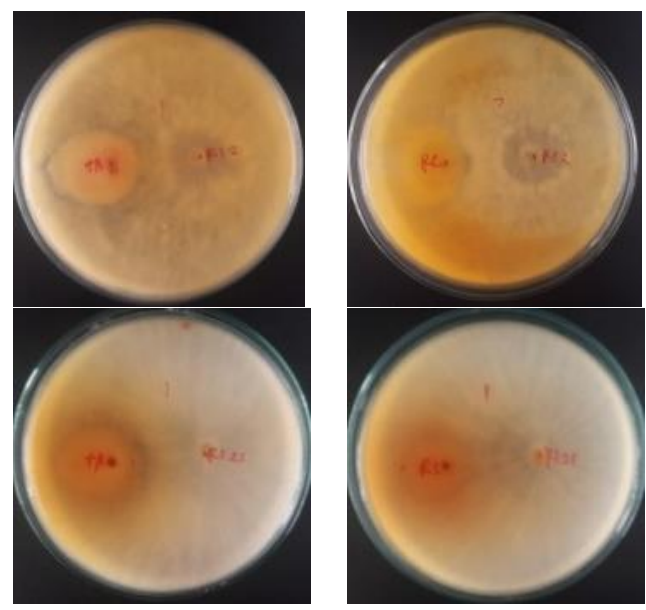

Figure 4. The inhibition of Trichoderma sp. against Fusarium sp., A. Trichoderma sp. (T1) against Fusarium F1 and F2 isolates, B. Trichoderma sp. (T2) against Fusarium F1 and F2 isolates

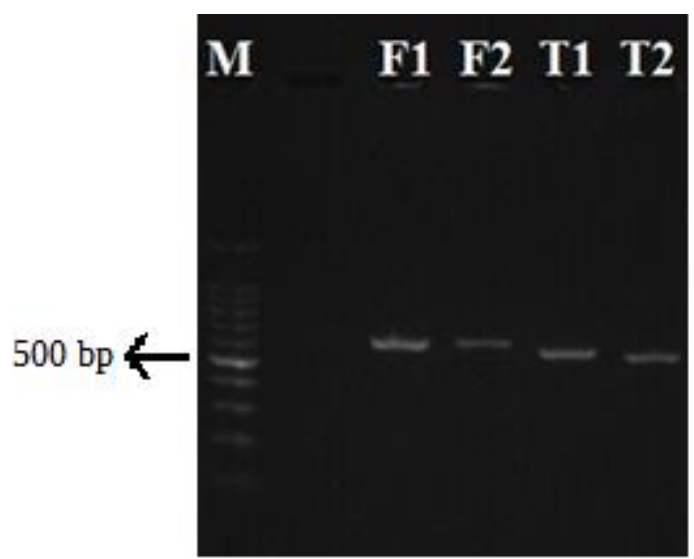

Figure 5. Amplified of ITS regions of Fusarium and Trichoderma isolates with primer ITS4/ ITS5; F1 and F2 are Fusarium isolates, T1 and $\mathrm{T} 2$ are Trichoderma isolates, while $\mathrm{M}$ is a marker.

abundantly, multinucleated, and germinate rapidly. It reproduces fungus efficiently. Macroconidia of Fusarium is straight or curved and thick [28]. Based on structures of microconidia, macroconidia, colony's pigments, and the other morphological characters, F1 was identified as Fusarium sp. (F1) and also F2 was identified as Fusarium sp. (F2).

\section{Morphological characteristic of Trichoderma isolates}

According to Ellis [22], Trichoderma sp. has yellowish colonies with surface textures like cot ton. Usually, it has a small zone like a concentric ring (Figure 3, T1). Based on Rianti [30] Trichoderma sp. grows fast and has a cotton-like texture. Trichoderma sp. has round conidia and conidiophores that has a bulkhead and branches. The main branch of the conidiophores arises directly from the main armpit. The conidiophores branching extends along the conidiophores [31].

\section{The potency of Trichoderma isolates to inhibit the growth of Fusarium isolates}

As biocontrol agents, Trichoderma (T1 and T2) were assayed for their inhibition against the two Fusarium isolates (F1 and F2). Both T1 and T2 rhizosphere Trichoderma isolates have different potency in inhibiting both of the Fusarium isolates (Figure 7). The inhibition percentages of the T1 isolate against the Fusarium isolates F1 and F2 were $65.4 \%$ and $74.5 \%$ respectively. On the other hand, T2 isolate has the inhibition potency of 70.3 $\%$ and $79.8 \%$ against the Fusarium F1 and F2 isolates respectively. Based on the previous result, Trichoderma asperellum was able to inhibit Fusarium oxysporum about 23-71\% after six days incubation [28]. Moreover, Trichoderma viride showed that the inhibition of the mycelial growth of Fusarium sp. is $52.31 \%$ [32].

Antibiosis is an antagonistic interaction involving antibiotics that are produced by a microorganism which is detrimental to the growth of pathogens [14]. Trichoderma spp. produce antibiotics such as gliovirin, gliotoxin, viridin, viridol, koninginins, pyrones, and peptaibols to inhibit the fungal phytopathogens [33, 34].

The most important factor for fungi is substrate competition [35]. At the very common reason for the death of many microorganisms growing around of Trichoderma is the starvation due to limited nutrients and for rhizospheric colonization.

The process of mycoparasitism involves a direct attack of one fungal species on another one. According to Singh [14], mycoparasitism is one of the main mechanisms involved in the antagonisms of Trichoderma. The events leading to mycoparasitism are complex, taking place as follows: Chemotropic growth of Trichoderma, recognition of the host, coiling and appressoria formation, secretion of hydrolytic enzymes, penetrations of the hyphae, and lysis of the host. 


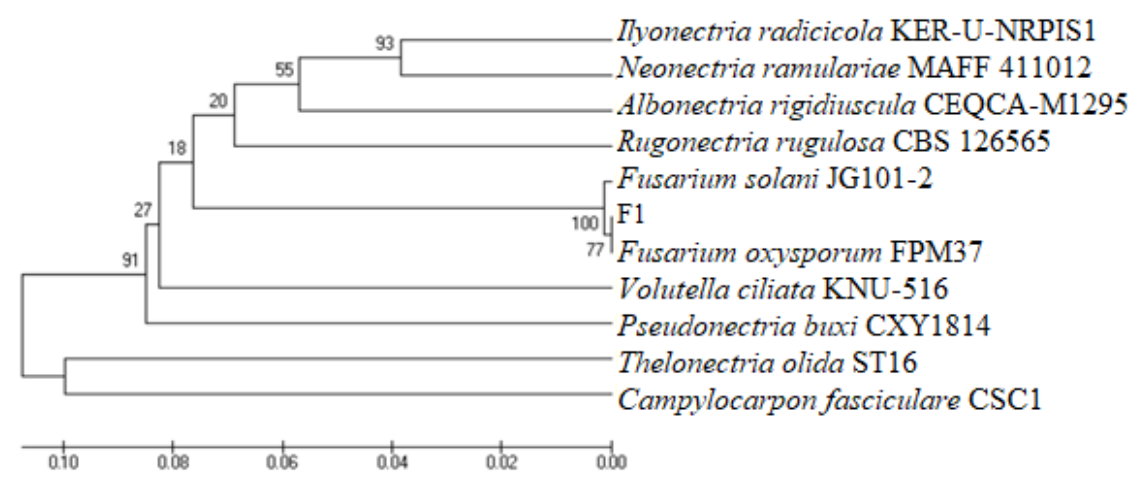

(a)

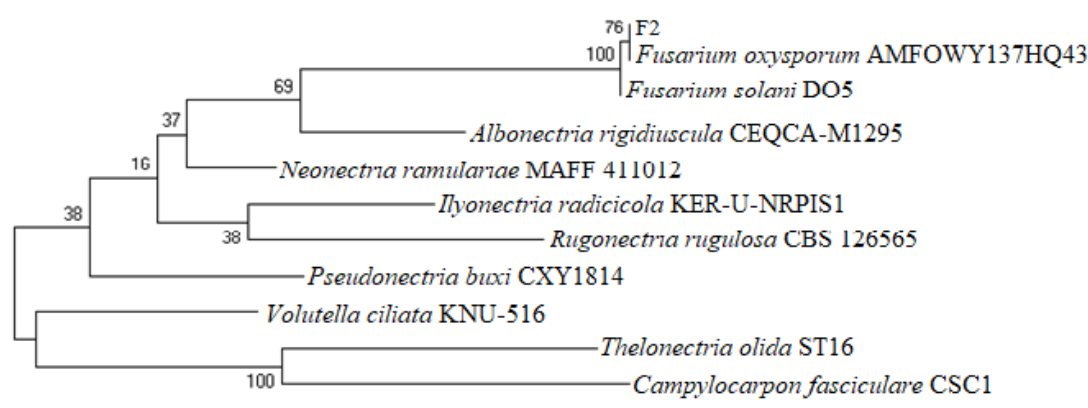

(b)

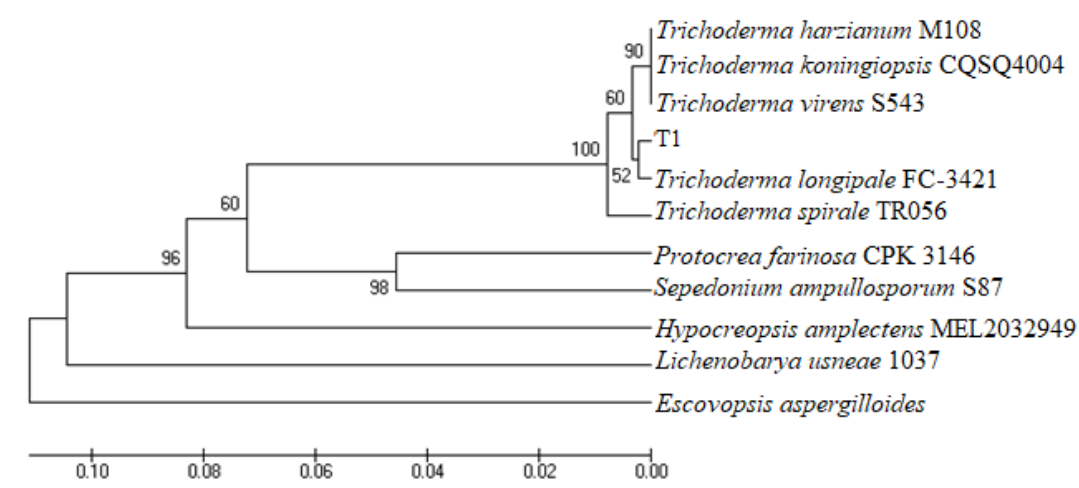

(c)

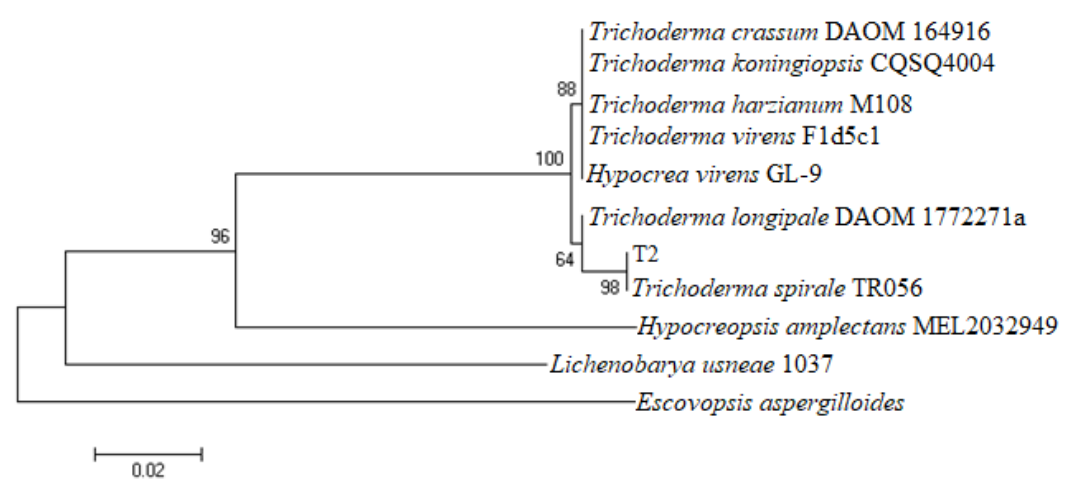

(d)

Figure 6. Phylogenetic tree generated using nucleotide sequence information of the ITS region by Maximum Likelihood (a and c) and UPGMA methods (b and d) 


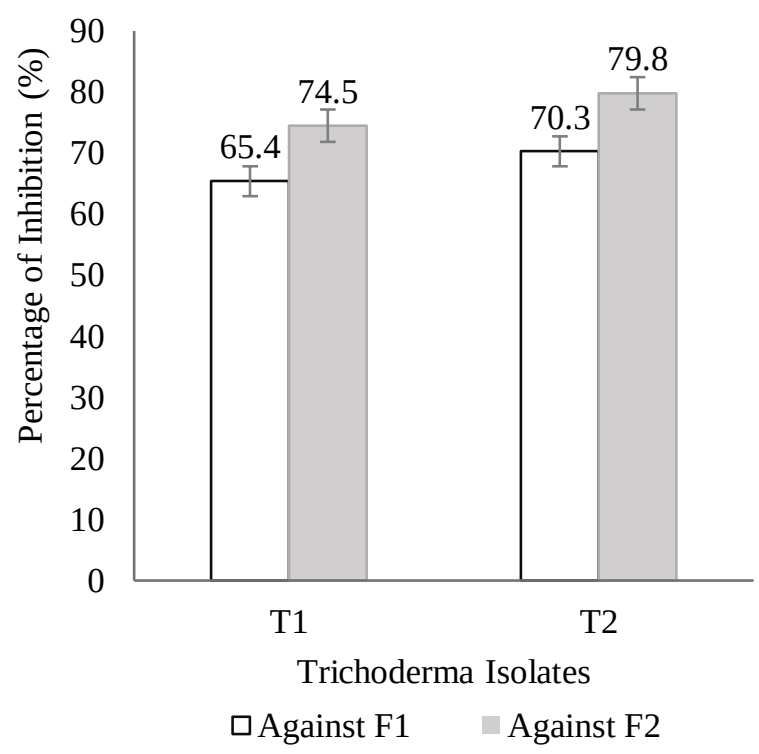

Figure 7. The potency of Trichoderma to inhibit the growth of Fusarium F1 and F2 on the $7^{\text {th }}$ day dual culture assay

The possible inhibition mechanism of both $\mathrm{T} 1$ and T2 isolates was competition since the Fusarium isolates were not able to grow well because of the limitation of nutrition and space for growth (Figure 4).

\section{Fungal species identified based on ITS}

The total size of the ITS4 and ITS5 regions of the isolates varied from 500 to 600 bp (Figure 5). Fusarium sp. and Trichoderma sp. sequences obtained from the amplification of conserved ribosomal ITS region was compared with the sequences from the NCBI database using BLAST 2.0 (http://www.ncbi.nlm.nih.gov/).

\section{Sequence analysis of ITS}

Phylogeny tree of Fusarium isolates (F1 and F2) and Trichoderma isolates (T1 and T2) was constructed based on the ITS sequence and was compared with the reference strains. ITS sequences of all isolates were aligned with the consensus region using the CLUSTAL $\mathrm{W}$ program with 1000 bootstrap replications. The topologies of the Maximum Likelihood and UPGMA trees were constructed using the MEGA version 6 program. The phylogenetic tree generated by the Maximum Likelihood explains that the probability of an evolutionary event at a certain point in the tree is stochastic modelled: below the maximum probability, the preferred phylogenetic tree is the tree with the highest probability. Besides, the UPGMA explains that the agglomerative hierarchical grouping is based on the average linkage method [36].

As shown in Figure 6, isolate F1 revealed a close phylogenetic relationship with Fusarium sp. F1 isolate had an identical sequence with Fusarium oxysporum FPM37 (100\%) (Figure 6A). Meanwhile, F2 was identified as Fusarium oxysporum AMFOWY137HQ43 (Figure 6B). Based on the microscopic characterization, both F1 and F2 isolates produced macroconidia abundantly and were curved and thick. The T1 and T2 isolates had the highest relationship with Trichoderma longipale FC-3421 (Figure 6C) and Trichoderma spirale TR-056 (Figure 6D) with the similarity value of $99.5 \%$ and $100 \%$ respectively. Meanwhile, based on colonies morphology and microscopic characterization, both $\mathrm{T} 1$ and $\mathrm{T} 2$ isolates have different characteristic. Trichoderma longipale (T1) has a small zone like a concentric ring, while Trichoderma spirale (T2) does not. They have cotton-like texture, round conidia, branching conidiophores, and grow rapidly.

\section{Conclusion}

Fusarium sp. 1 (F1) and Fusarium sp. 2 (F2) isolates were found in $A$. muelleri tuber rot. Trichoderma sp. 1 (T1) and Trichoderma sp. 2 (T2) have the potency to inhibit the growth of both the Fusarium isolates. Isolate T2 has the highest potency as an antagonist for the tuber rot fungi.

Both Fusarium isolates were identified as Fusarium oxysporum, while T1 and T2 were identified as Trichoderma longipale and Trichoderma spirale respectively. Trichoderma spirale has the best potential to be developed as a biological control agent against the tuber rot fungi $F$. oxysporum.

\section{Acknowledgment}

The authors are thankful to the Brawijaya University for providing the laboratory facilities to carry out this present study, to Ministry of Research and Technology Republic of Indonesia for the financial support and to the Porang farmer in Bantur sub-district, Malang Regency for providing the valuable tubers.

\section{References}

1. Arisoesilaningsih E, Indriyani S, Retnowati R, Fernandes AAR (2009) Pemodelan pertumbuhan vegetatif dan produksi umbi 
porang pada beberapa umur tanaman, kondisi vegetasi, tanah dan iklim agroforestri. Research Report. Universitas Brawijaya. Malang.

2. Yuzammi, Kurniawan A, Asih NPS et al. (2017) The Amorphophallus of Indonesia. Center for Plant Conservation Botanic Gardens - Indonesian Institute of Sciences, Bogor.

3. Widjanarko SB, Faridah A, Sutrisno A (2011) Effect of multilevel ethanol leaching on physico-chemical properties on konjac flour (Amorphophallus oncophyllus). In The $12^{\text {th }}$ Asean Food Conference: 16-18.

4. Katayama K, Teramoto T (1997) Seed potato production and control of insect pests and diseases in Indonesia. Agrochemicals Japan (70): 22-25.

5. Rengwalska MM, Simon PW (1986) Laboratory Evaluation of Pink Root and Fusarium Basal Rot Resistance in Garlic. Plant Disease Journal (70): 670-672. doi: 10.1094/pd-70-670.

6. Yu L, Zhao J, Liu J et al. (2015) Identification of postharvest pathogens of Amorphophallus muelleri and indoor screening of fungicides. Journal of Agricultural Science and Technology A 5: 577 - 584. doi: 10.17265/2161-6256/2015.07.002.

7. Bockus WW, Bowden RL, Hunger RM et al. (2007) Compendium of wheat diseases and insects, 3rd Edition. APS Press, St. Paul, MN.

8. Singha IM, Kakoty Y, Unni BG et al. (2016) Identification \& characterization of Fusarium sp. using ITS \& RAPD causing fusarium wilt of tomato isolated from Assam, North East India. Journal of Genetic Engineering \& Biotechnology 14 (1): 99105. doi: 10.1016/j.jgeb.2016.07.001.

9. Bentley S, Pegg KG, Moore NY et al. (1998) Genetic variation among vegetative compatibility groups of Fusarium oxysporum f. sp. cubense analyzed by DNA fingerprinting. Phytopathology Journal 88: 1283 - 1293. doi: 10.1094/phyto.1998.88.12.1283.

10. Wibowo A, Subandiyah S, Sumardiyono C et al. (2011) Occurrence of tropical race 4 of Fusarium oxysporum $\mathrm{f}$. sp. cubense in Indonesia. The Plant Pathology Journal 27 (3): 280 - 284 doi: 10.5423/ppj.2011.27.3.280.

11. Melysa, Fajrin N, Suharjono, Dwiastuti ME (2013) Potensi Trichoderma sp. sebagai agen pengendali Fusarium sp. patogen tanaman strawberry (Fragaria sp.). Jurnal Biotropika 1 (4): 177 $-181$.

12. Ferniah RS, Daryono BS, Kasiamdari RS, Priyatmojo A (2014) Characterization and pathogenicity of Fusarium oxysporum as the Causal Agent of Fusarium wilt in chili (Capsicum annuum L.). Microbiology Indonesia 8 (3): 121 - 126. doi: 10.5454/mi.8.3.5

13. Benítez T, Rincón AM, Limón MC, Codón AC (2004) Biocontrol mechanisms of Trichoderma strains. International Microbiology 7: $249-260$.
14. Dubey SC, Suresh M, Singh B (2007) Evaluation of Trichoderma species against Fusarium oxysporum f.sp. ciceris for integrated management of chickpea wilt. Biological Control 40 (1): 118 - 127. doi: 10.1016/j.biocontrol.2006.06.006.

15. Singh A, Shukla N, Kabadwal BC, Tewari AK, Kumar J (2018) Review on Plant-Trichoderma-Pathogen interaction. International Journal of Current Microbiology and Applied Sciences 7 (2): 2382 - 2397. doi: 1020546/ijcmas.2018.702.291.

16. Liza EY, Adrinal, Trisno J (2015) Keragaman cendawan rizosfer dan potensinya sebagai agens antagonis Fusarium oxysporum penyebab penyakit layu tanaman krisan. Jurnal Fitopatologi Indonesia 11 (2): 68 - 72. doi: 10.14692/jfi.11.2.68.

17. Rebecca LJ, Dhanalakshmi V, Sharmila S et al. (2012) Isolation, identification and characterization of fungi from rhizosphere soil of Barleria Cristata. International Journal of Horticultural \& Crop Science Research 2 (1): 1 - 6.

18. Dhiva S, Pillai HPJ, Shinde VM (2016) isolation and characterization of soil microorganisms for potential biocontrol activity. International Journal of Current Research in Biosciences and Plant Biology $3 \quad$ (3): $26 \quad-\quad 29$ doi: 10.20546/ijcrbp.2016.303.005

19. Shi M, Chen L, Wang X et al. (2012) Antimicrobial peptaibols from Trichoderma pseudokoningii induce programmed cell death in plant fungal pathogens. Microbiology 158: 166-175. doi: 10.1099/mic.0.052670-0.

20. Pradana GS, Ardyati T, Aini LQ (2013) Eksplorasi Kapang Antagonis dan Kapang Patogen Tanaman Apel di Lahan Perkebunan Apel Poncokusumo. Jurnal Biotropika 1 (1): 14 - 18.

21. Shohihati L, Suharjono (2014) Uji potensi \& identifikasi molekular kapang antagonis untuk mengendalikan kapang patogen tanaman apel di perkebunan apel Gabes, Department of Biology, Faculty of Mathematics and Natural Sciences. Malang. Thesis.

22. Chandrashekar M, Soumya P, Raju N (2014) Fungal diversity of rhizosphere soils in different agricultural fields of Nanjangud Taluk of Mysore district, Karnataka, India. International Journal of Current Microbiology and Applied Sciences 3 (5): 559 - 566.

23. Ellis D, Davis S, Alexiou H et al. (2007) Descriptions of fungi 2nd Edition. Nexus Print Solution, Adelaide.

24. Sibounnavong PK, Soytong CC, Divina, Kalaw (2009) In-vitro biological activities of Emericella nidulans, a new fungal antagonist, against Fusarium oxysporum f. sp. lycopersici. Journal of Agricultural Technology 5 (1): 75 - 84.

25. Lestari FW, Suharjono, Arumingtyas EL (2013) Phylogenetic identification of pathogenic fungi from apple in Batu City, Malang, Indonesia. Advances in Microbiology 3 (1): 69 - 75. doi: 10.4236/aim.2013.31011.

26. GoTaq ${ }^{\circledR}$ Green Master Mix (2012) Promega Corporation USA http://www.promega.com. 
27. Ohara T, Tsuge T (2004) FoSTUA, encoding a basic helix-loophelix protein, differentially regulates development of three kinds of asexual spores, macroconidia, microconidia, and chlamydospores, in the fungal plant pathogen Fusarium oxysporum. Eukaryotic Cell 3 (6): 1412 - 1422. doi: 10.1128/ec.3.6.14121422.2004.

28. Leslie J, Summerell B (2006) The Fusarium laboratory manual. Blackwell Publishing Ltd., Oxford.

29. Hafizi R, Salleh B, Latiffah Z (2013) Morphological and molecular characterization of Fusarium solani and F. oxysporum associated with crown disease of oil palm. Brazilian Journal of Microbiology 44 (3): 959 - 968. doi: 10.1590/s151783822013000300047.

30. El Komy, Saleh AA, Eranthodi A, Molan YY (2015) Characterization of novel Trichoderma asperellum isolates to select effective biocontrol agents against tomato Fusarium wilt. The Plant Pathology Journal 31 (1): 50 - 60. doi: 10.5423/PPJ.OA.09.2014.0087.

31. Rianti R (2010) Uji antagonis Trichoderma harzianum terhadap Fusarium spp. penyebab penyakit layu pada tanaman cabai (Capsicum annum) secara in vitro. Universitas Tanjungpura. Pontianak. Thesis.
32. Samson RA, Houbraken J, Thrane JC et al. (2010) Food and Indoor fungi. Fungal Biodiversity Centre Utrecht, The Netherlands.

33. Verma NP, Kaur I, Masih H et al. (2017) Efficacy of Trichoderma in controlling Fusarium wilt in tomato (Solanum lycopersicum L.). Research in Environment and Life Sciences 10 (7): $636-639$.

34. Howell CR (2003) Mechanisms employed by Trichoderma species in the biological control of plant diseases: The history and evolution of current concepts. Plant Disease 87 (1): 4 - 10. doi: 10.1094/PDIS.2003.87.1.4.

35. Harman GE, Howell CR, Viterbo A et al. (2004) Trichoderma species - opportunistic, avirulent plant symbionts. Nature Reviews Microbiology 2: 43 - 56. doi: 10.1038/nrmicro797.

36. Viterbo A, Wiest A, Brotman Y et al. (2007) The 18mer peptaibols from Trichoderma virens elicit plant defence responses. Molecular Plant Pathology 8(6): 737-746. doi: 10.1111/j.13643703.2007.00430.x.

37. Pavlopoulos GA, Soldatos TG, Barbosa-Silva A, Schneider R (2010) A reference guide for tree analysis and visualization. BioData Mining 3 (1): 1-16. doi: 10.1186/1756-0381-3-1. 